Topic-based Regulation: Media Law and Data Protection 



\section{Media Law Regulation of Social Networks - Country Report: Germany}

Bernd Holznagel, Jan Christopher Kalbhenn

Abstract: In 2018, the German Federal Constitutional Court identified dangers in digitalisation of the media. This leads to "increased difficulty in the separation of fact from opinion, content from advertisement, as well as to new uncertainties regarding the credibility of sources and assessments. Individual users themselves must now process and assess the information provided by the mass media, which would traditionally have passed through the filter of professional selection in the spirit of responsible journalism." German lawmakers have responded to this with the Interstate Media Treaty. For the first time, this treaty sets requirements for content providers on social networks and addresses platforms as content distributors. Supplementary requirements result from the recent case law of the civil courts. The legislature is placing high demands on digital offerings by public broadcasters, who are no less required to provide a counterweight to the dangers of the network and platform economy.

Keywords: content moderation; due diligence; media law; disinformation; hate speech; algorithmic transparency; filter systems; recommendation systems; public service broadcaster; social media; public European space; design specifications

\section{Chapter 1. Increased need for truthful information on the Internet}

Initially, there was little knowledge about the novel Corona virus. At the same time, strategies to contain the pandemic required the cooperation of citizens and affected everyone's daily lives. This triggered an increased need for information. Without the filtering function of professional journalism, individuals would have been lost in the flood of news and information. Consequently, the first lockdown was also accompanied by an increase in media usage. The internet had the highest gains (19 percentage points) in informative daily reach. This includes informative use of 
algorithmic-driven online platforms. One in two people used Google, Facebook and the like to obtain information during the Corona pandemic (increase: 22 percentage points). In Germany, public information and news services are also represented there and generate high demand figures. ${ }^{1}$ Since the outbreak of the pandemic, the podcast charts have frequently been topped by the "Coronavirus Update." In it, virologist Christian Drosten regularly explains the latest scientific findings. At the same time, however, offers that spread misinformation also gained in reach. For the German-speaking world, these include the YouTube channels of CompactTV, SCHRANG TV and Games of Truth, which attempted to prove connections between the Corona outbreak and the expansion of the new $5 \mathrm{G}$ mobile communications standard. False information spread via social networks, such as that Corona immunity could be obtained injecting disinfectant. Internationally active is the conspiracy theorist network QAnon, which spreads the theory that Bill Gates, the Rothschild family and others have invented Corona as a bioweapon.

\section{Chapter 2. State duty to protect the democratic discourse}

The discourse model of the German Constitution (Grundgesetz) can only function if political will is formed on the basis of arguments. Social, economic and cultural challenges can only be solved on the basis of facts. In a battle of opinions, the better arguments should win. The German constitution also assumes that public opinion is formed through speech and counter-speech. This takes place through argumentative disputes in the public sphere. The state must stay out of it. However, it has a constitutional duty to protect. ${ }^{2}$ Thus, it must shape a positive media order in such a way that the "diversity of existing opinions finds expression in the broadest possible range and completeness." The word 'diversity' in this context is by no means to be equated with the word 'multiplicity'. ${ }^{3}$

It is questionable whether current media law legislation is able to ensure that the public is also supplied with factually correct and credible information on the internet and in social media. It is true that the possibilities of digital distribution channels such as social networks have led

1 Data for Germany in Bernd Holznagel and Jan Kalbhenn, Monitoring Media Pluralism in the digital Era - Country Report Germany (2021).

2 Steinebach et al., Desinformation aufdecken und bekämpfen, (Baden-Baden: Nomos, 2020).

3 Horst Röper, Konzentration und Vielfalt im deutschen Rundfunk, UVK Medien, 1997. 
to a differentiation and multiplication of offerings. In this regard, the Bundesverfassungsgericht (German Federal Constitutional Court) also states that offerings are often not aimed at diversity of opinion, but are "determined by one-sided interests or the economic rationality of a business model, namely to maximise the time users spend on pages as much as possible and thereby increase the advertising value of the platform for customers." The highest German court also sees a danger in the fact that content is specifically tailored to the interests and inclinations of users by algorithmic means. In this respect, results in search engines are also pre-filtered and partly financed by advertising, partly dependent on "click numbers". ${ }^{4}$

As a result, the Federal Constitutional Court states that digitisation of the media leads "to increased difficulty in the separation of fact from opinion, content from advertisement, as well as to new uncertainties regarding the credibility of sources and assessments. Individual users themselves must now process and assess the information provided by the mass media, which would traditionally have passed through the filter of professional selection in the spirit of responsible journalism."

When the highest court points out such dangers to democratic discourse, it is tantamount to a mandate for legislators to address the problems and consider whether they must fulfil their duty to protect. At the end of 2020, the German states, which are responsible for media law, adopted the Medienstaatsvertrag (Interstate Media Treaty, in short: $\mathrm{MStV}) .{ }^{5}$ For the first time, this sets specifications for content providers on social networks (III.). Platforms as content distributors are also addressed, with additional requirements arising from the recent case law of the civil courts (IV.). The legislator places high demands on the digital offerings of public service broadcasters, who are expected to do no less than act as a counterweight to the dangers of the network and platform economy (V.).

4 Bundesverfassungsgericht, Decision from 18 July 2018 - BVerfGE 149, 222 („Rundfunkbeitrag“").

5 English version of the Interstate Media Treaty under https://www.die-medienanstal ten.de/fileadmin/user_upload/Rechtsgrundlagen/Gesetze_Staatsvertraege/Interstate _Media_Treaty_en.pdf. 


\section{Chapter 3. Media law requirements for content on social networks}

\section{Chapter 3.a. Journalistic standards of due diligence}

Due diligence obligations for the press and broadcasting have long been known in German media law. These providers must check news for content, origin and truth with the due diligence required by the circumstances before disseminating it. The German Press Code serves as a benchmark in this regard. ${ }^{6}$ In it, the German Press Council sets out guidelines aimed at truthfully informing the public and enhancing the credibility and reputation of the media. The Press Code also includes the requirement to treat facts as such with care and the requirement to separate editorial and advertising publications. In connection with reporting on a study on the Corona infectivity of children, the Press Council reprimanded the biggest national (boulevard) newspaper BILD in 2020 for breaches of the duty of care. The paper had suppressed several facts important for understanding the study and had obscured a study result that was unpopular in some political circles, namely that children also transmit the Corona virus.

These journalistic standards of care have so far applied on the internet only to the offerings of radio stations and press publishers. Other providers, such as offerings distributed as podcasts or via YouTube by digital native news providers, were not bound by standards and appropriate oversight. Misrepresenting a study here would not be reprimanded on the basis of a journalistic due diligence violation. However, much false information is disseminated via channels whose presentation can hardly be distinguished at first glance from news sources operating according to high standards. Such offerings are widely disseminated via platforms such as YouTube and Instagram. The Interstate Media Treaty extended the obligation to observe journalistic standards to this area as well. ${ }^{7}$ Now the rules also apply to "other journalistic-editorial telemedia which regularly contain news or political information".

Things now get complicated when it comes to supervising compliance with these standards. In contrast to the other information services, the online offerings of the press are generally exempt from supervision by the state media authorities. Self-regulation is given priority for information services. They are given the option of joining the Press Council or a volun-

6 Press code of the German Press Council https://www.presserat.de/pressekodex.htm 1.

7 \ $19 \mathrm{MStV}$. 
tary self-regulation institution. Nevertheless, supervision by the competent state media authority will take place alongside. Voluntary self-regulatory bodies require approval by the state media authorities, and their decisions are subject to review and objection by those authorities. For services not affiliated with voluntary self-regulation, the state media authorities are directly responsible. ${ }^{8}$

\section{Chapter 3.b. Labelling of social bots}

In the debate about disinformation, the role of social bots is regularly emphasised. This refers to computer programs that are used on social networks to produce automated content and messages and that appear to originate from a human. To be sure, opinions still differ on the extent to which such computer programs are already being used effectively. However, a new study on media education in Germany shows that digital media education is in a poor state and that many digital phenomena cannot be classified. ${ }^{9}$ Social bot programs, for example, are in danger of jeopardizing democratic discourse. ${ }^{10}$ Bots can be used to distort public opinion by pushing certain content en masse. Bots can also simply disseminate false information and support the virality of certain harmful content. The Interstate Media Treaty now introduces mandatory labelling for providers of social bots on social networks such as Facebook, TikTok, Twitter and YouTube. If such accounts are operated there, the account holders must make the fact of automation known. This is intended to take account of the fundamental potential of these programs to influence individual and public opinion-forming, without completely banning the use of such services. A complete ban on social bots can probably not be justified, if only because they can also be used for harmless and non-political purposes, such as customer advice. In the implementation of these new rules, it will be important that the labels are made in such a way that they are effective and that the users of social networks can classify the accounts accordingly. In practice, this will require the expertise of media designers and media

8 Bernd Holznagel and Jan Christopher Kalbhenn, "Journalistische Sorgfaltspflichten auf YouTube und Instagram“, in Festschrift für Jürgen Taeger, ed. SpechtRiemenschneider et al. (Frankfurt: R\&W, 2020), 589-608.

9 https://www.stiftung-nv.de/sites/default/files/studie_quelleinternet.pdf (last accessed: 15 April 2021).

10 Christian Grimme et al., "Demystifying Social Bots: On the Intelligence of Automated Social Media Actors", Social Media \& Society Vol. 6, Nr. 3 (2020) 1-14. 
psychologists. Through statutes and case law, concrete requirements for the interface design of social networks can develop from this (design requirements).

The addressees of these obligations are also the social networks. They must ensure that service providers comply with the labelling obligation. How they do this is up to the networks to decide. The only rule is that they must do so carefully. ${ }^{11}$

\section{Chapter 3.c. Labelling of political advertising}

The business model of many open platforms, such as social networks, is based substantially to exclusively on advertising. This business model allows the reach of content to be scaled in return for monetary payments. Micro-targeting is considered particularly effective in this context. The advertiser can then have its advertising message displayed to a target group that it can precisely determine in advance on the basis of individual criteria. This is possible because the platforms create incredibly detailed profiles of their users. To advertise baby food, it then makes sense for the advertiser to target young mothers with a certain income. In the analog world, this would require advertising in an appropriate magazine or in the context of an appropriate TV show without the involvement of personal data. $^{12}$

A further risk situation that must be taken into account first arises in the case of political advertising. ${ }^{13}$ For example, micro-targeting can be used by a political party to make different 'election promises' to certain selected groups of voters. Young families can be promised more child benefit, while the same party promises to cut child benefit for another voter group and to do more for the care of dogs and cats (dark ads).

Classic media law recognises that political advertising on TV and radio has long been a particularly sensitive category of advertising. It is only permitted under strict conditions in a short period before elections. Otherwise, a strict ban applies. The possibility of banning political advertising on social networks also presented itself with the Interstate Media Treaty, which for the first time contains rules for political advertising in the digital

$11 \rrbracket 18$ Sec. $3 \mathrm{MStV}$.

12 Shoshana Zuboff, The Age of Surveillance Capitalism: The Fight for a Human Future at the New Frontier of Power (New York: PublicAffairs, 2019).

13 Judit Bayer, "Double harm to voters: data-driven micro-targeting and democratic public discourse", Internet Policy Review 9(1) (2020). 
realm. ${ }^{14}$ To avert danger, however, the initial focus is on transparency. A labelling obligation for political, ideological and religious advertising will be introduced for all telemedia. This transparency obligation is intended to provide better information about the origin and financing of such advertising. For this reason, the relevant advertisers or clients must be clearly indicated in an appropriate manner. The state media authorities are responsible in each case. The specific dangers of microtargeting are not addressed. The regulation applies to this type of advertising just as it does to such advertising that is displayed to all users of a platform or website. To be fruitful as a tool in the fight against disinformation and contradictory campaign promises, the concept of advertising in this context must be interpreted widely. It must cover all political content whose relevance is promoted by payments to the networks. Otherwise, difficult demarcations may arise. For example, parties and politicians are increasingly using layouted messages that cannot initially be distinguished from paid advertising in purely visual terms.

\section{Chapter 3.d. Interim conclusion}

The regulations presented are a clear step forward in combating the spread of disinformation. In the 2016 US election campaign and the Brexit referendum in the same year, so-called dark ads, non-transparent micro-targeting, and social bots in particular were identified as influencing public opinion. With labelling requirements for social bots and political advertising, transparency rules for these problems are now available for the first time. However, the regulations found by the legislature are quite challenging in terms of oversight and enforcement. Many demarcation issues will arise, so that an intensive learning process lies ahead for those involved. This becomes particularly clear in the area of supervision of compliance with journalistic due diligence obligations. Here, the circle of obligated parties is greatly expanded with the information services in the Interstate Media Treaty. ${ }^{15}$ But in supervision, too, the state media authorities and institutions of voluntary self-regulation join the Press Council. The regula-

$14 \$ 22$ Sec. $3 \mathrm{MStV}$.

$15 \$ 19$ Sec. $1 \mathrm{MStV}$. 
tions proposed by the European Commission in the Digital Services Act go much further, especially in the area of advertising. ${ }^{16}$

\section{Chapter 4. Media law requirements for content moderation on social networks}

More and more people are turning to platforms such as Facebook and YouTube for information or news. Just under one in two adult Germans $(48 \%)$ has also obtained information about the virus from social media. In the 18- to 24 -year-old group, the figure is 72 percent. ${ }^{17}$ Journalistic editorial content is also displayed in the Facebook newsfeed or on YouTube. The success or dissemination of disinformation, but also of truthful information, on the internet depends in many cases on platform content moderation. Central to the architecture of the platforms are the filtering and recommendation systems that decide which content comes onto the platforms and which users are shown which content. The programming and the underlying relevance criteria of algorithms thus determine the visibility and reach of content. Content that is recommended by algorithms and also shared by people has a strong chance of becoming viral and achieving an extraordinary reach. Filtering systems that suppress, devalue or delete illegal and harmful content have the effect of curbing reach. For the first time, the new Interstate Media Treaty lays down regulations regarding these systems and thus also regarding content moderation on social networks, as well as flanking design specifications. Particularly harmful and criminal content must be deleted quickly under the rules of the Netzwerkdurchsetzungsgesetz (Network Enforcement Act, in short: NetzDG). Initial legal guidelines for the measures used by platforms to combat disinformation on the basis of their general terms and conditions and community standards can be taken from civil court case law. For the first time, the Interstate Media Treaty also formulates positive findability rules for public value content on digital platforms.

16 Jan Kalbhenn and Maximilian Hemmert-Halswick, "EU-weite Vorgaben zur Content-Moderation auf sozialen Netzwerken“, ZUM - Zeitschrift für Urheber- und Medienrecht No. 3 (2021), 184.

17 Sascha Hölig and Uwe Hasebrink, Digital News Report-Germany (20220) https:// www.hans-bredow-institut.de/uploads/media/default/cms/media/66q2yde_AP50_ RIDNR20_Deutschland.pdf. 
Chapter 4.a. Specifications for recommendation and filtering systems

\section{a) Transparent recommendation algorithms}

For the first time, the new Interstate Media Treaty takes a look at content moderation by recommendation systems. It requires certain platforms to make the central criteria of aggregation, selection, and presentation of content visible. ${ }^{18}$ However, this obligation under media law applies to those platforms "which also aggregate, sort and publicly disseminate thirdparty editorial content". ${ }^{19}$ Journalistically editorial offers, i.e. those that contribute to the formation of opinion through a planned activity with the aim of producing and promptly passing on an offer, are disseminated by all common social networks. These must disclose the sorting criteria. This transparency obligation is limited by protection of trade and business secrets, which is why, according to the explanatory memorandum to the law, the algorithm itself does not have to be published. The precise formulation of the transparency rule is left to the state media authorities. They must specify the requirements in statutes that apply nationwide. ${ }^{20}$ They will require that the relative weighting of the individual criteria be described. The platforms' optimisation goals should also be transparent. Social networks must then also specify how exactly the findability of content can be influenced by monetary payments and what role profiling plays in this. Information on the architecture and design of the platforms will also be necessary, namely to disclose what influence the functions available to users (sharing, liking, and the like) have.

\section{b) Transparent filter algorithms}

Before content can even be captured by recommendation systems, it must first be posted on the platforms. During this process, they are already checked by the social network filter systems and, if necessary, not published at all. These filter systems are particularly advanced in the area of copyright. YouTube's content management system has long been con-

$18 \rrbracket 93 \mathrm{MStV}$.

$19 \$ 2 \mathrm{MStV}$.

20 „Satzung der Landesmedienanstalten über die Regulierung von Medienintermediären gemäß $\$ 96$ Medienstaatsvertrag“ Draft of the Statue notified at the Commission can be found in the database https:/ec.europa.eu/growth/tools-databases/ tris/en/search/. 
sidered particularly sophisticated and detects possible copyright infringements within a few seconds by comparing uploaded content with content already known in the archive. Systems for detecting "harmful" content that is not tolerated according to platform community standards also filter out content that constitutes hate speech, terrorism, or similar content on a large scale. The Interstate Media Treaty also responds to the use of such filtering systems with a transparency requirement. The social networks must disclose the criteria that determine whether a piece of content can be accessed and remain on the platform. These might, for example, be technical, economic, provider-related, user-related and content-related requirements. Information on content categories, the purpose of the measures, and possibilities of influence through payment must also be made transparent.

\section{c) Prohibition of discrimination of journalistic content}

Both the recommendation systems and the filtering systems are subject to a new prohibition of discrimination in favour of journalistic and editorial offerings in the Interstate Media Treaty. ${ }^{21}$ This is intended to prevent certain offerings from being over- or under-represented in comparison to other editorial offerings, for example, due to their political orientation or organisational form (private or public) of the provider, and to directly or indirectly impair access or findability.

However, the threshold for the existence of discrimination under the Interstate Media Treaty is quite high; only discrimination of a systematic nature is prohibited. The duration, regularity, possible repetition and systematic nature of the discrimination must be taken into account. A distinction is drawn between two groups of cases of discrimination. Firstly, if the criteria to be published in accordance with the transparency requirements are deviated from without objective reason in favour of or to the detriment of a specific offer. Secondly, if bids are directly or indirectly unfairly systematically impeded by these criteria.

Discrimination may be justified in individual cases. In addition to technical reasons (e.g., displayability of the offering on mobile devices), justification can also be based on lawful conduct. For example, copyright assessments. 


\section{d) Design specifications}

The Interstate Media Treaty stipulates that information on recommendation systems and filtering systems must be "easily perceivable, immediately accessible and constantly available". How this is to be understood will become clear in the medium term. If criteria for easy perceptibility emerge through statutes and case law, this will result in concrete requirements for the design of social networks. The NetzDG makes similar design specifications for the discoverability of complaint options. ${ }^{22}$ Here, experience shows that some networks in practice tend to hide the possibility to use the Network-Enforcement-Act-complaint-tools in their design of the user interface. As a consequence, the legislator could feel compelled to set stricter criteria for "easy noticeability", which would then have to be implemented by (product) designers.

\section{Chapter 4.b. Expeditious deletion of certain criminal content}

Legal concretisations for the rapid deletion of content are contained in the NetzDG. The law is intended to safeguard rational discourse online and combat the spread of false news via social networks. However, the specified deadlines for deleting illegal content only apply to the catalogue of 22 criminal offences defined in the NetzDG, only a few of which in turn relate to the potential spread of false news (e.g. defamation under Section 187 of the Criminal Code).

Deletions under the NetzDG have so far been of little consequence for Facebook. In the first half of 2020, Facebook deleted 3,913 pieces of content, Twitter 122,302 on the basis of the NetzDG. ${ }^{23}$ With the amendment to the NetzDG, the legislator is attempting to push back deletions according to community standards by making it easier to find the complaint option under the NetzDG and expanding reporting obligations. A "put-back" procedure is introduced to safeguard the rights of data subjects under Article 5 (1) of the Grundgesetz. In the future, a position will also be taken

22 Jan Kalbhenn and Maximilian Hemmert-Halswick, „Netzwerkdurchsetzungsgesetz“in: Handbuch Multimedia-Recht, ed. Hoeren/Holznagel/Sieber (München: C. H. Beck, 2021), part 21.3.

23 "NetzDG Transparenzbericht July 2020" Facebook https://about.fb.com/wp-con tent/uploads/2020/07/facebook_netzdg_July_2020_German.pdf; "Community Standards Enforcement Report, Third Quarter 2020,” Facebook, https://transpare ncy.facebook.com/community-standards-enforcement. 
on the use of automated procedures for finding content in transparency reports. Another new way of monitoring content is for those affected to go before a conciliation body. These bodies, which have yet to be established, are to mediate as a low-threshold service for those affected and open up the possibility of involving civil society. This regulatory regime is becoming more differentiated. ${ }^{24}$

\section{a) Establishment of voluntary self-regulation}

For example, the first recognised institution of voluntary self-regulation, Voluntary Self-Regulation of Media Service Providers (FSM), has been available since March 2020 for the area of content monitoring under the NetzDG. FSM is a non-profit association and membership is open to companies from the Online Media Sector. In the case of illegality that is difficult to assess, network providers are to be able to consult the FSM. For example, in cases of satire and political opinion campaigns, the limits of freedom of expression are traditionally more difficult to fathom. It is therefore not surprising that this group of cases is frequently represented among the FSM's first cases. Most recently, the panel of 50 lawyers had to judge a comment on Facebook explaining how a standard text can be used to circumvent the mask requirement when shopping. Here, the FSM denied the offence of public solicitation to commit a crime. All decisions are available online. ${ }^{25}$ This is how a canon for content control on social networks can be created.

\section{b) Case Study "Liberation of Germany from the Merkel Regime"}

A post on Facebook was calling for action against the "Merkel Regime". ${ }^{26}$ It reads as follows: "Half a million to a million Germans plan to demonstrate on August 1 in Berlin, a great opportunity to liberate Germany from the Merkel regime (Freemasons' puppet). Tens of thousands of Germans must storm into the Chancellery, occupy entire buildings, and the Committee to Rescue Germany takes over government. (...) The parliamentary

24 Kalbhenn and Hemmert-Halswick, Netzwerkdurchsetzungsgesetz.

25 Online Archive of FSM to be accessed under https://www.fsm.de/de.

26 FSM „Entscheidung Aktenzeichen NetzDG0092020“ https://www.fsm.de/de, (translation by the authors). 
party system is past and finished, now the people, parliament and the Committee to rescue Germany decide on a future Germany. Merkel and the whole cabinet and colleagues, all party functionaries of the CDU, CSU, FDP, SPD, Greens and the LEFT, all constitutional judges, ARD ZDF directors and moderators, all the lying press (newspapers) owners and reporters, fascist terrorist Antifa groups, all must be arrested immediately for high treason, and a military court must decide on the fate of these traitors. (...) destroy all Masonic Lodges with their members - Soros - Bill Gates-Antifa-Greta-EU-NATO, destroy all Anti-Christian Party politicians, Islamists, Anti-Christian leaders (Cardinals, Bishops) in the Vatican official church who are Freemasons' puppets (...)".

This post could qualify as public provocation to commit crimes under the German Criminal Code. Then the content would be unlawful in the sense of the NetzDG and would have to be deleted. But this decision is not easy. Facebook also did not find the assessment easy and made use of the option to submit the case to the FSM. In order to be recognised as a self-regulatory body, institutions must meet a number of requirements. The installation of such self-regulated bodies is provided for in the NetzDG. These bodies must meet certain requirements prescribed by law to be recognised by the Federal Office of Justice. These lawyers are paid by the FSM. For example, they have to secure proper equipment for the examiners, guarantee a rapid testing within seven days and provide transparent rules of procedure. According to its procedural rules the FSM works in several "Audit Committees". These Audit Committees are composed of three persons, who appoint a chairman from among themselves. They work in line with a schedule of responsibilities. The Committee members are installed for at least one year, and must have the qualification for the office of a judge. Incompatibility rules define who is not allowed for the task, for example lawyers working for the same law firm representing the company, lawyers appointed by social networks, and employees of media authorities. Only social networks that are members of the FSM are entitled to submit applications. The procedure to be followed is prescribed as well. Social networks can request the FSM to decide on a case by email. These applications must meet formal requirements, for example in regard to their completeness. The FSM administrative office forwards the case to the competent audit committee, which has to decide within seven days. The committee can decide by telephone or in writing. The final decision must be submitted in writing and contain facts and reasons. It must state whether submitted content is unlawful in the sense of the NetzDG. All decisions must be published. If the submitted content is unlawful, the social network must take immediate action. The FSM procedure also has 
complaint options. The uploader can request a review of the FSM decision. The deadline for this is two weeks and it may lead to a new decision. FSM decisions must be based on current German jurisdiction. The examination is limited to the question whether content is unlawful in the sense of NetzDG.

It was according to these rules that this self-regulated body dealt with the "The Merkel Regime" case. The FSM considered human rights and the jurisprudence of Federal Constitutional Court.

In this case the FSM considered and weighted the fundamental right of freedom of expression (Art. 5 Grundgesetz) and used leading judgements of the Federal Constitutional Court as a benchmark for its examination. It recalled the Federal Constitutional Court and said: "when interpreting expressions of opinion that aim to influence the opinion-forming process and are subject to freedom of opinion, the content of the declaration must also be determined against the background of social and political events". The FSM decided in favour of the User, namely that the post on Facebook does not constitute unlawful content in the sense of the NetzDG.

\section{Chapter 4.c. Civil court requirements for content moderation according to community standards}

According to its community standards, Facebook took action against 22.5 million pieces of content globally for hate speech from April to June $2020 .{ }^{27}$ This may also affect content that is still protected by freedom of expression, such as certain forms of conspiracy theories or fake news. This raises the question of the extent to which private platforms are bound by freedom of expression when providing a public communication space. With regard to Facebook, the Federal Constitutional Court has already stated that it is "precisely for the dissemination of political programmes and ideas [...] a medium of paramount importance that is not readily replaceable" and that exclusion from the platform denies an essential opportunity to disseminate political messages and actively engage in discourse with users. ${ }^{28}$

27 "NetzDG Transparenzbericht July 2020" Facebook https://about.fb.com/wp-con tent/uploads/2020/07/facebook_netzdg_July_2020_German.pdf; "Community Standards Enforcement Report, Third Quarter 2020,” Facebook, https://transpare ncy.facebook.com/community-standards-enforcement.

28 Bundesverfassungsgericht, Decision from 22 May 2019 - 1 BvQ 42/19 („III. Weg“). 


\section{a) Hate speech}

Community standards and platform content deletions based on them are fully reviewable in the German civil courts. There is already a broad canon of case law on paragraph 12 of community standards (hate speech). When examining the legality of the deletion decision in civil court, the courts first deal with the effectiveness of the platform Terms of Service. In Clause 12, Facebook reserves the right to delete hate speech, which it defines "as a direct attack on individuals based on protected characteristics: ethnicity, national origin, religious affiliation, sexual orientation, caste, gender, gender identity, serious illness or serious disability." The majority of courts consider Clause 12 (hate speech) to be a permissible contractual clause. Under German constitutional law, fundamental rights also apply between private actors. The courts then weigh the fundamental rights positions of the users (freedom of expression and the principle of equality) against those of the platforms (fundamental economic rights). Emphasis is placed on Facebook's interest in structuring its terms of use in its own business interests in such a way that people with different backgrounds and different values and moral concepts feel as unaffected and comfortable as possible. The restriction on users' freedom of expression is mitigated by the fact that, in principle, "humour and social criticism," among other things, are permitted in connection with topics covered by hate speech. Occasionally, courts recognise in the community standards an unreasonable disadvantage contrary to good faith, because operators of a public marketplace for information such as Facebook must ensure that a lawful expression of opinion is not removed. ${ }^{29}$ Deletion can then only be considered if content is illegal, for example, if it violates one of the provisions of Section 1 (3) NetzDG.

\section{b) Fact-checking}

So-called fact-checking in particular is sometimes seen as a proven antidote to disinformation. Paragraph 21 of Facebook's Community Standards states: "We want to help people stay informed without hindering productive public discussion." Following a partially automated process established by Facebook, potential fake reports are identified and submitted to

29 Kalbhenn and Hemmert-Halswick, Netzwerkdurchsetzungsgesetz for an overview on Jurisprudence of German Courts. 
service providers for review. They can then flag the report accordingly, triggering a significant reach restriction. By default, the fact-checker's website is also linked to a call for donations.

The Karlsruhe Higher Regional Court (Oberlandesgericht) had to decide on a specific case of fact-checking on Facebook. An article by a medium called Tichys Einblick linked on Facebook had the headline "500 scientists declare: 'There is no climate emergency'." Facebook's fact-checking service provider 'Correctiv' inextricably linked the corresponding post with the note "fact-check" and "assertion partly false." The reasoning for that labelling was that not all signatories of the declaration mentioned in the article were "scientists".

The Oberlandesgericht Karlsruhe assumed an anti-competitive business act here since both Tichys Einblick and Correctiv were media outlets competing for attention. ${ }^{30}$ Because freedom of opinion also applies between private actors under German constitutional law, the court consequently sets standards for fact-checking that would apply accordingly to a state actor. Thus, in journalistic competition, the duty of neutrality must be observed: Certain opinions or tendencies may not be favoured or disadvantaged by promotion. The principle of equal opportunity in communication must be observed: If the credibility of a particular participant in journalistic competition is particularly emphasised or publications would always include a reference to the opposing view or even all competing views, this would require special justification. The fact-checker must be particularly careful to avoid any misunderstanding as to which statement their criticism refers to, who made the statement, and whether the criticism is primarily evaluative or factual in nature. Incorrect information does not constitute an asset worthy of protection from the point of view of opinion formation.

\section{Chapter 4.d. Findability of truthful content in user interfaces}

In view of the flood of information, it is important that socially significant information and news offerings in particular can be found by the user community at all. Media policy has long called for making it easier to find public value offerings. The Interstate Media Treaty now introduces findability rules, but only for smart TV devices, streaming sticks and smart

30 Oberlandesgericht Karlsrube, Decision from 09 September 2020, - 6 U 38/19 („Tichys Einblick“). 
speakers. ${ }^{31}$ Public value offerings must be made easy to find through a highlighted presentation. These are primarily offerings by public broadcasters. Commercial offerings can also be specified by the state media authorities. This is intended to take into account the increasing importance of findability and positively ensure diversity.

Netflix and Amazon Prime, which are in particularly high demand among young people, are not subject to any obligations to make certain content easy to find or to grant access to the offering in the first place. This recognises the editorial sovereignty and programming of these services, as is familiar with other final media products (newspapers, TV programming). Facebook Newsfeed, Google Search or YouTube are also not subject to any discoverability rules as so-called media intermediaries. Corresponding demands failed in the countries where these companies have their German headquarters. Here, trust is still placed in self-regulation by providers. However, architecture specifications for the platforms are also possible. Under certain conditions, they could be required to programme their algorithms for diversity.

\section{Chapter 5. Interim conclusion}

Digital platforms are the main channel for dissemination of fake news, because the effects of communication based on algorithms can increase the spread enormously ("viral effects"). Regulation in this area is just becoming more differentiated in Germany. On the one hand, this applies to the Interstate Media Treaty, which provides transparency and non-discrimination rules for recommendation systems and filtering systems, but which only protects journalistic and editorial content. For content that is found to be criminal, the NetzDG requires expeditious deletion, but the decision-making process for this is distributed among various pillars and all parties involved are protected by procedural rules. The Digital Services Act also follows these regulatory approaches, even in some cases going beyond them. ${ }^{32}$ Furthermore, the platforms have plenty of room to shape their content moderation and also align it with their economic goals. The case law of the civil courts provides some initial guidelines in this regard. In July 2021, the Federal Court of Justice ruled that it is necessary for Facebook to undertake in its terms and conditions to inform the user

$31 \rrbracket 84 \mathrm{MStV}$.

32 Kalbhenn and Hemmert-Halswick, EU-weite Vorgaben zur Content-Moderation. 
concerned about the removal of a post at least retrospectively and about an intended blocking of his user account in advance, to inform him of the reason for this and to give him an opportunity to respond, followed by a new decision. ${ }^{33}$ What is sorely lacking for digital platforms is, above all, discoverability rules for high-quality content, such as that of public broadcasters.

\section{Chapter 6. High requirements as to content of public service media}

The services provided by public broadcasters continue to enjoy high priority in Germany. In addition to a nationwide TV service (ZDF) and radio service (Deutschlandradio), public broadcasting is organised on a federal basis. Nine broadcasters distribute TV and radio programmes. Since 2019, broadcasters have also been increasingly active on the internet. The broadcasters' Corona coverage has been well received and approval ratings are at a high level. ${ }^{34}$ However, rapid developments in the area of digital platform competition are causing problems. The development of public broadcasting is regularly driven by the case law of the Federal Constitutional Court. In 2018, the court defined the mission of public broadcasting in the digital world and also positioned it against disinformation and other threats fuelled by the network and platform economy.

\section{Chapter 6.a. Public service broadcaster as "counterweight"}

In 2018, the Federal Constitutional Court had to rule on a completely different question, but did not miss the opportunity to define the role of contribution-financed public broadcasting in the digital media world. The network and platform economy of the internet, including social networks, leads to "increasingly difficult separability between facts and opinion, content and advertising, as well as to new uncertainties regarding the credibility of sources and evaluations. The individual user must take over the processing and mass media evaluation that traditionally takes place

33 Bundesgerichtshof Decision from 29 July 2021 - III ZR 179/20 und III ZR 192/20, press release unter https://www.bundesgerichtshof.de/SharedDocs/Pressemitteilu ngen/DE/2021/2021149.html.

34 Nationwide survey Infratest Dimap, "Glaubwürdigkeit der Medien 2020, Auftraggeber: WDR https://www1.wdr.de/unternehmen/der-wdr/unternehmen/studie -deutsche-medien-glaubwuerdig-106.html. 
through the filter of professional selections and responsible journalistic action." ${ }^{35}$ For the court, it follows that in view of this development, the importance of the task incumbent on contribution-financed public broadcasting grows "through authentic, carefully researched information that keeps facts and opinions apart, does not present reality in a distorted way and does not put the sensational in the foreground, but rather forms a counterweight that ensures diversity and offers guidance." 36

\section{Chapter 6.b. Expansion of entitlements for online program}

For a long time, the public broadcaster was only allowed to post in its media libraries the programmes already broadcast linearly, limited to seven days. In order to be able to form the counterweight demanded by the Federal Constitutional Court, a significant expansion of the public broadcaster's scope for action was created in 2019.37 The core point of the reform was to mandate broadcasters to produce and distribute content that is oriented to the specifics of the internet and social media (i.e., online only). Thus, the mandatory reference of online offerings to a previously linear broadcast was abandoned. Content in media libraries can now also be available for longer than a week. In addition, broadcasters are authorised to network their content with each other. They are also to do this with the digital offerings of public cultural and educational services. Furthermore, the online offerings of broadcasters are to provide guidance, enable all population groups to participate in the information society, offer interactive communication, and promote the technical and content-related media competence of all generations and minorities. Information, education and advice are among the legal core tasks of public service telemedia as well. In this context, the principles of objectivity and impartiality of reporting, diversity of opinion, and balance of offerings must be taken into account.

Nevertheless, it is questionable whether public broadcasting can hold its own against international streaming platforms from Hollywood or Silicon

35 Bundesverfassungsgericht, Decision July 182018 - BVerfGE 149, 222 („Rundfunkbeitrag“").

36 Bundesverfassungsgericht, Decision July 182018 - BVerfGE 149, 222 („Rundfunkbeitrag").

37 Jan Kalbhenn and Christian Schepers, "Öffentlich-rechtliche Telemedien und digitale Kommunikationsplattformen - Die digitalen Angebote von ARD, ZDF und Deutschlandradio auf Instagram, Netflix und Spotify“, K\&R - Kommunikation und Recht, No. 5 (2021), 316-322. 
Valley despite these possibilities. ${ }^{38}$ In the medium term, this would probably require the development of a platform of its own.

\section{Chapter 6.c. Further development into a public interest-oriented platform}

Even before Netflix launched its service in Germany, ARD and ZDF had plans for a joint VOD streaming portal by 2014. These public broadcasters wanted to build a joint platform for accessing movies, series and other programmes. To this end, their own pool of content was to be supplemented by third-party content. A subscription model and an advertising-financed variant were planned. However, the German Federal Cartel Office was sceptical about the concept and expressed concern that the planned platform would have prevented other alternative platforms from entering the market. Just a few years later, this legal opinion would have been dismissed as absurd. As a result, there are increasing calls for a platform under public law that is to be oriented toward the common good. In the European context, plans are afoot for a digital platform for quality content. ${ }^{39}$ In essence, this is an alternative to the existing monopoly providers Facebook and Google. The platform is to bring together the media libraries of public and private broadcasters, portals of publishers and cultural institutions such as universities, museums, and archives. In addition to this curated part, the platform is also to include various aggregating functions: in addition to search engines, these could also be 'citizen accounts' for mutual exchange. It should promote social cohesion and be committed to a citizen-friendly approach to Big Data. On the content side, competition is to prevail. A concept for this is now available. According to this, the "European Public Sphere" is to be designated as an open digital ecosystem divided into different levels and components. The basic technology is a cloud infrastructure as the foundation of the ecosystem. On top of this, on a second level, technology platforms are to provide applications such as "video player," "search," "translation," and "identity" as building blocks. Levels one and two form central elements for an open and digital ecosystem. Thus, a third

38 Hennig-Thurau et al., Angriff aus Hollywood. Was es für den deutschen Streamingund Fernsehmarkt bedeutet, wenn Hollywood-Studios zu Konkurrenten werden, 2021, 26, https:/www.marketingcenter.de/sites/mcm/files/downloads/news/2021/lmm_ angriff_aus_hollywood.pdf.

39 Henning Kagermann and Ulrich Wilhelm (publisher), "European Public Sphere. Gestaltung der digitalen Souveränität Europas“, acatech (2020). 
level should be able to provide a variety of offerings. Public services can use the infrastructure to offer smart city or e-school applications. ${ }^{40}$

\section{Figure: Graphics from Henning Kagermann and Ulrich Wilhelm (publisher), 'European Public Sphere. Gestaltung der digitalen Souveränität Eu- ropas', acatech (2020).}

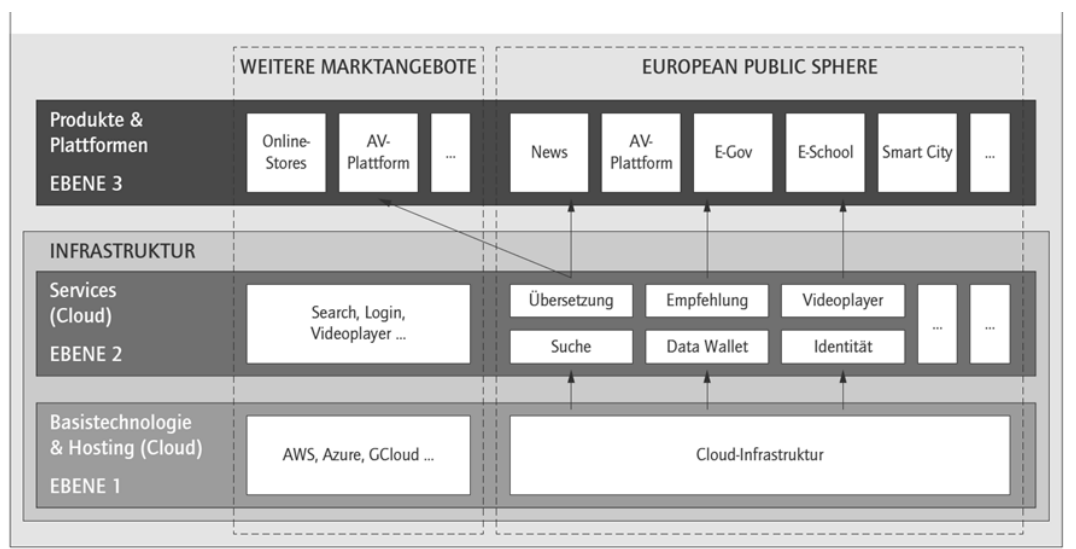

One focus of the model is on digital media. The concept paper states that the "European Public Sphere" is characterised in the area of digital media by offerings whose content and functionality can keep pace with today's content offerings. In addition, users should be offered new opportunities to form their own and public opinions. International diversity through European content should enable citizens to develop broader perspectives on diverse topics. Finally, the concept states, "Transparent rules of conduct and control mechanisms will prevent fake news and filter bubbles and enable open, democratic discourse. At all times, there is trust in the protection of one's own data."

40 Graphics taken from Kagermann and Wilhelm, "European Public Sphere. Gestaltung der digitalen Souveränität Europas“. 


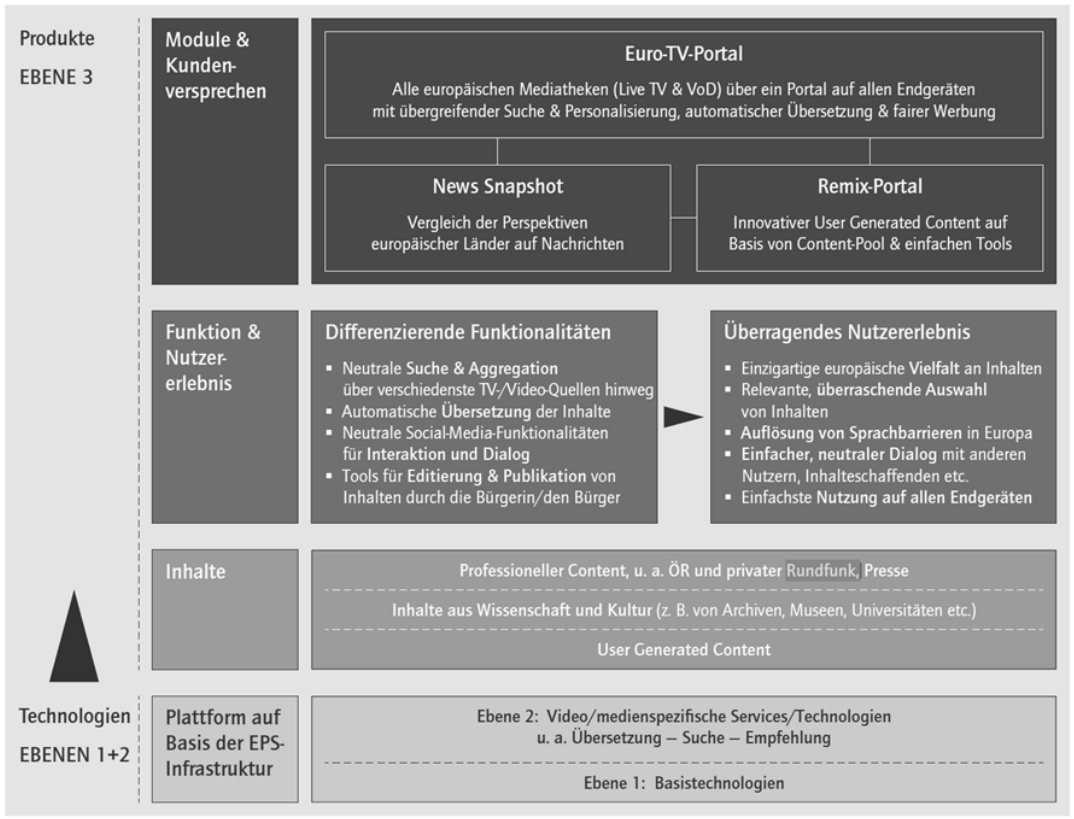

The state must lead the way in such a solution. The digital infrastructure can only be created via a state effort. But the political will must be there. At the very least, existing public offerings at national and European levels should be linked to each other and to offerings from the fields of culture and science. These are not platform solutions, but they are better than nothing in view of rapid developments. How such a solution is to be financed has not yet been clarified. At present, the financing of the conventional offering is being put to the test.

\section{Chapter 6.d. Funding of public service content}

In Germany, public broadcasters have a constitutional right to funding in line with their needs. The structural and programming decisions of broadcasters in connection with provision of telemedia services and the associated cost requirements therefore also enjoy constitutional protection. For 
the years 2021 to 2024, this amounts to a fixed EUR 1371.1 million. ${ }^{41}$ The independent expert panel of the KEF (Commission to Determine the Financial Requirements of Public Service Broadcasting) has recommended raising the broadcasting contribution by 86 cents from EUR 17.50 to a total of EUR 18.36 per household per month from January 1, 2021. The state governments of all the federal states must agree to this. At the end of 2020, this failed in the state parliament of Saxony-Anhalt. The broadcasters initiated proceedings before the Federal Constitutional Court, in which many legal questions will be raised but also the future impact of digital public value offerings as a counterweight will be decided.

Chapter 7. Overview of instruments

\begin{tabular}{|c|c|c|}
\hline & $\begin{array}{l}\text { Interstate } \\
\text { Media } \\
\text { Treaty }\end{array}$ & NetzDG \\
\hline Transparency reporting & & - \\
\hline Timely Deletion of severe criminal content & & - \\
\hline $\begin{array}{l}\text { Cooperation with national authorities follow- } \\
\text { ing orders }\end{array}$ & & घ \\
\hline $\begin{array}{l}\text { Points of contact and, where necessary, legal } \\
\text { representative }\end{array}$ & - & - \\
\hline $\begin{array}{l}\text { Notice and action and obligation to provide } \\
\text { information to users }\end{array}$ & & - \\
\hline $\begin{array}{l}\text { Complaint and redress mechanism and out of } \\
\text { court dispute settlement }\end{array}$ & & - \\
\hline \multicolumn{3}{|l|}{ Trusted flaggers } \\
\hline Findability of Public Service Content & - & \\
\hline Labelling of Social Bots / Chatbots & 口 & \\
\hline Labelling of political advertising & 口 & \\
\hline Reporting criminal offences & & 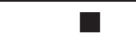 \\
\hline
\end{tabular}

41 See 22. KEF-Bericht, Rn. 56., https://kef-online.de/fileadmin/KEF/Dateien/Bericht e/22._Bericht.pdf. 


\begin{tabular}{|l|l|c|}
\hline & $\begin{array}{l}\text { Interstate } \\
\text { Media } \\
\text { Treaty }\end{array}$ & NetzDG \\
\hline $\begin{array}{l}\text { Risk management obligations and compli- } \\
\text { ance officer }\end{array}$ & & \\
\hline Transparency of recommender systems & $\mathbf{-}$ & \\
\hline Data sharing with authorities and researchers & & $\mathbf{\square}$ \\
\hline $\begin{array}{l}\text { Non-Discrimination clause for journalistic } \\
\text { content }\end{array}$ & $\mathbf{-}$ & \\
\hline Crisis response cooperation & & \\
\hline
\end{tabular}

\section{Chapter 8. Conclusion}

False information poses a risk to society as well as to the individual. The media legislator has recognised this and consequently introduced initial instruments. However, blanket solutions are not offered. The regulations presented concern a differentiated group of obligated parties and, in addition to transparency and due diligence obligations, also strive for discoverability privileges for certain content. A valuable asset in the fight against misinformation is Germany's strong public broadcasting system. It is mandated and empowered to act as a counterweight on the internet. It is impossible to predict whether the rules in the Interstate Media Treaty will be effective in ensuring credible information, especially since enforceability will be challenging. Initial experience with the instruments can be fruitful in the discussions about the Digital Services Act and the Artificial Intelligence Act, ${ }^{42}$ whose draft contains similar instruments, some of which go further. ${ }^{43}$

The synopsis of the instruments and measures presented should be understood as a learning system. A wide variety of factors play a role in the spread of misinformation. In addition to a wide variety of actors (states, organisations, individuals) with different interests (economic, racial, polit-

42 Jan Kalbhenn, "Designvorgaben für Chatbots, Deepfakes und Emotionserkennungssysteme: Der Vorschlag der Europäischen Kommission zu einer KI-VO als Erweiterung der medienrechtlichen Plattformregulierung“, ZUM - Zeitschrift für Urheber- und Medienrecht, No. 8/9 (2021).

43 See Chapter of Jan Kalbhenn "European legislative initiative for very large communication platforms". 
ical), technology is the most important factor. This, however, is subject to continuous change. According to Moore's Law, the complexity of integrated circuits doubles every 12 months. The platform-dominated and algorithm-driven world of communication also comes up with new technologies and tools at ever shorter intervals. Platforms are continuously changing their design and their architecture, drawing on the insights of leading cognitive psychologists. In the Netflix documentary "The Social Media Dilemma," design ethicist Tristan Harris, formerly of Google, explains that many design features of social media are borrowed directly from the gambling industry's Las Vegas experience. This does not make the difficult undertaking of guaranteeing supply of trustworthy information any easier. Rather, it should be an incentive to defend the public debate space on the internet against commercial interests with a digital platform oriented toward the common good under the strong leadership of public broadcasting. This is an inter- and transdisciplinary task with computer scientists, designers, cognitive scientists and economists to be involved.

\section{Bibliography}

Assenmacher, Dennis, Lena Clever, Lena Frischlich, Thorsten Quandt, Heike Trautmann, and Christian Grimme. 'Demystifying Social Bots: On the Intelligence of Automated Social Media Actors.' Social media + society 6, no. 3 (July-September 2020): 1-14. https://doi.org/10.1177/2056305120939264.

Bayer, Judit. 'Double harm to voters: data-driven micro-targeting and democratic public discourse' Internet Policy Review 9(1) (2020).

Deutscher Presserat. 'Publizistische Grundsätze (Pressekodex). Richtlinien für die publizistische Arbeit nach den Empfehlungen des Deutschen Presserats. Beschwerdeordnung.' Accessed 20 April 2021. https://www.presserat.de/pressek odex.html.

Facebook. 'Community Standards Enforcement Report.' Accessed 20 April 2021. https://transparency.facebook.com/community-standards-enforcement.

Facebook. 'NetzDG Transparenzbericht.' 2020. Accessed 20 April 2021. https://abo ut.fb.com/wp-content/uploads/2020/07/facebook_netzdg_July_2020_German.pd f.

Hennig-Thurau, Thorsten, Ricarda Schauerte, Niko Herborg, Veronika Schneid, and Nico Wiegand. 'Angriff aus Hollywood. Was es für den deutschen Streaming und Fernsehmarkt bedeutet, wenn Hollywood Studios zu Konkurrenten werden.' 2021. Accessed 20 April 2021. https://www.marketingcenter.de/sites/m $\mathrm{cm} /$ files/downloads/news/2021/lmm_angriff_aus_hollywood.pdf. 
Hoeren, Thomas, Ulrich Sieber, und Bernd Holznagel. Handbuch MultimediaRecht. Rechtsfragen des elektronische Geschäftsverkehrs. München: C. H. Beck, 2021.

Hölig, Sacha and Uwe Hasebrink. 'Reuters Institute Digital News Report 2020. Ergebnisse für Deutschland. Unter Mitarbeit von Julia Behre.' Arbeitspapiere des Hans-Bredow-Instituts. Projektergebnisse Nr. 50. Hamburg: Verlag HansBredow-Institut, 2020. Accessed 20 April 2021. https://www.hans-bredow-institu t.de/uploads/media/default/cms/media/66q2yde_AP50_RIDNR20_Deutschland. pdf.

Holznagel, Bernd and Jan Christopher Kalbhenn. ,Journalistische Sorgfaltspflichten auf YouTube und Instagram', in Festschrift für Jürgen Taeger, ed. SpechtRiemenschneider et al. (Frankfurt: R\&W, 2020): 589-608.

Holznagel, Bernd and Kalbhenn, Jan. ,Monitoring Media Pluralism in the digital Era - Country Report Germany 2021' Florence (2021). Accessed 20 August 2021. https://cadmus.eui.eu/bitstream/handle/1814/71947/germany_results_mp m_2021_cmpf.pdf?sequence=1\&isAllowed=y

Kagermann, Henning und Ulrich Wilhelm. 'European Public Sphere. Towards Digital Sovereignty for Europe', acatech, (2020). Accessed 20 April 2021. https:// www.acatech.de/publikation/european-public-sphere/.

Kalbhenn, Jan Christopher and Christian Schepers. 'Öffentlich-rechtliche Telemedien und digitale Kommunikationsplattformen - Die digitalen Angebote von ARD, ZDF und Deutschlandradio auf Instagram, Netflix und Spotify' Kommunikation und Recht, no. 5 (2021).

Kalbhenn, Jan Christopher and Maximilian Hemmert-Halswick. 'EU-weite Vorgaben zur Content-Moderation auf sozialen Netzwerken', ZUM, no. 3 (2021): 184-194.

Kalbhenn, Jan and Maximilian Hemmert-Halswick, ,Netzwerkdurchsetzungsgesetz', in: Handbuch Multimedia-Recht, ed. Hoeren/Holznagel/Sieber (München: C. H. Beck, 2021), part 21.3.

Kalbhenn, Jan, Designvorgaben für Chatbots, Deepfakes und Emotionserkennungssysteme: Der Vorschlag der Europäischen Kommission zu einer KI-VO als Erweiterung der medienrechtlichen Plattformregulierung', ZUM - Zeitschrift für Urheber- und Medienrecht, No. 8/9 (2021) 663-674.

Kohl, Helmut. Vielfalt im Rundfunk - Interdisziplinäre und internationale Annäherungen, UVK Medien, 1997.

Kommission zur Ermittlung des Finanzbedarfs der Rundfunkanstalten. '22. Bericht.' Februar 2020. Accessed 20 April 2021. https://kef-online.de/fileadmi n/KEF/Dateien/Berichte/22._Bericht.pdf.

Martin Steinebach, Katarina Bader, Lars Rinsdorf, Nicole Krämer, and Alexander Roßnagel. Desinformation aufdecken und bekämpfen. Interdisziplinäre Ansätze gegen Desinformationskampagnen und für Meinungspluralität. Baden-Baden: Nomos, 2020. 
Meßmer, Anna-Katharina, Alexander Sängerlaub, and Leonie Schulz. "Quelle Internet?" Digitale Nachrichten- und Informationskompetenzen der deutschen Bevölkerung im Test.' Accessed 20 April 2021. https://www.stiftung-nv.de/sites/ default/files/studie_quelleinternet.pdf.

Specht-Riemenschneider, Louisa, Benedikt Buchner, Christian Heinze, and Oliver Thomsen. Festschrift für Jürgen Taeger. Frankfurt am Main: Deutscher Fachverlag $\mathrm{GmbH}$, Fachmedien Recht und Wirtschaft, 2020.

WDR. 'Mehr Menschen halten Medien in Deutschland für glaubwürdig.' 2020. Accessed 20 April 2021. https://www1.wdr.de/unternehmen/der-wdr/unternehm en/studie-deutsche-medien-glaubwuerdig-106.html.

Zuboff, Shoshana. 'The Age of Surveillance Capitalism: The Fight for a Human Future at the New Frontier of Power.' New York: PublicAffairs, (2019). 
